\title{
Giant Ovarian Thecoma Associated with Meigs' Syndrome: A Striking Case
}

\author{
Dionysios Dellaportas ${ }^{1 *}$, Dimitra Kollia ${ }^{1}$, Despoina Myoteri², Constantinos Nastos ${ }^{1}$, George Gkiokas ${ }^{1}$, \\ Eleni Carvounis ${ }^{2}$, Theodosios Theodosopoulos'
}

12nd Department of Surgery, 'Aretaieion' University Hospital, Medical School of Athens, Greece

'Department of Pathology, 'Aretaieion' University Hospital, Medical School of Athens, Greece

${ }^{*}$ Corresponding author:

Dionysios Dellaportas, MD, PhD, FEBS (ECS)

$2^{\text {nd }}$ Department of Surgery

'Aretaieion' University Hospital

Medical School of Athens

115 28, Greece

E-mail: dellapdio@gmail.com

\section{Rezumat}

Tecom ovarian gigant în contextul sindromului Meigs: un caz surprinzător

Introducere: Sindromul Meigs constă în prezența unei tumori ovariene benigne, însoțită de ascită şi de revărsat pleural care se remit după excizia chirurgicală a formațiunii tumorale. Nivelul de Ca-125 crescut în acest context poate fi derutant, însă este rareori raportat.

Prezentarea cazului: O femeie în vârstă de 46 de ani, cu o formațiune tumorală pelvină / abdominală gigantă, cu originea în anexa dreaptă, ascită şi revărsat pleural, cu Ca-125 crescut (938 UI / ml), a fost internată cu diagnosticul prezumtiv de cancer ovarian în stadiul IV. Investigațiile imagistice au evidențiat o formațiune tumorală ovariană, solidă, cu diametrul de $22 \mathrm{~cm}$. S-a practicat histerectomie totală cu anexectomie bilaterală, omentectomie şi s-au drenat $4 \mathrm{~L}$ de lichid de ascită. În mod surprinzător, examenul histopatologic a infirmat caracterul malign, stabilind diagnosticul de tecom ovarian. Ascita şi revărsatul pleural s-au remis în primele 7 zile postoperator, indicând diagnosticul de sindrom Meigs.

Discutie: sindromul Meigs reprezintă 1\% din totalitaea tumorilor ovariene. $\mathrm{Cu}$ toate acestea, ar trebui luat în considerare în diagnosticul diferențial atunci când clinicienii întâlnesc triada clasică a sindromului, chiar şi atunci când Ca-125 este crescut. Aceşti pacienți au o speranță de viață normal, însă fiziopatologia acestei afecțiuni rămâne incertă din anumite puncte de vedere.

Cuvinte cheie: tecom ovarian, fibrom ovarian, sindrom Meigs, revărsat pleural, tumoră ovariană 


\begin{abstract}
Introduction: Meigs' syndrome consists of the presence of a benign ovarian tumor, ascites and pleural effusion, and the latter two subdued after surgical excision of the ovarian tumor. Elevated Ca-125 in this context is confusing and is reported only in a handful of cases. A rare but striking case with the above features is presented herein.

Case Presentation:A 46-year-old woman with a giant pelvic/abdominal mass originating from her right adnexa, ascites and pleural effusion, with elevated Ca-125 (938 IU/mL) was treated with the presumptive diagnosis of stage IV ovarian cancer. Imaging modalities showed a $22 \mathrm{~cm}$ solid adnexal mass and the patient underwent total abdominal hysterectomy and bilateral salpigooophorectomy, omentectomy and drainage of $4 \mathrm{~L}$ of ascetic fluid. Surprisingly, final histopathology was negative for malignancy, characterizing the primary tumor as ovarian thecoma. Ascites and pleural effusion resolved by the seventh postoperative day, setting the diagnosis of Meigs' syndrome. Discussion:Meigs' syndrome accounts for $1 \%$ of all ovarian tumors, however it should be considered in the differential diagnosis when clinicians come across the classic triad of the syndrome, even when $\mathrm{Ca}-125$ is elevated. These patients have normal life expectancy with meticulous management, while pathophysiology of this condition remains uncertain in various points.
\end{abstract}

Key words: ovarian thecoma, ovarian fibroma, Meigs' syndrome, pleural effusion, adnexal tumor

\section{Introduction}

Meigs' syndrome is defined as the triad of a. benign ovarian tumor with $b$. ascites and $c$. pleural effusion, while all of these features are subdued after resection of the primary tumor (1). Ovarian fibromas comprise the majority of the benign tumors resulting in Meigs' syndrome. This syndrome's peculiar clinical characteristic is that the presence of ascites and pleural effusion does not always indicate malignancy, on the contrary it does usually resolve after primary tumor excision (2). However, the diagnosis can be only accurately defined postoperatively. Histologically, the underlying benign ovarian tumor may be a fibroma in most cases, while thecoma, cystadenoma, or granulosa cell tumor are also reported basically as case reports (3).

A striking case of a 46-year-old woman with a giant ovarian mass, elevated $\mathrm{Ca}-125$ and finally Meigs' syndrome, with excellent clinical course is presented herein and pathophysiology and clinical characteristics of this unusual syndrome are highlighted.

\section{Case Report}

A 46-year-old woman with clear medical history, was admitted to the hospital for worsening abdominal distension with a palpable mass in the abdomen. The patient was in knowledge of a gradually increasing ovarian tumor, first diagnosed 15 years ago and on her last follow up two years ago she was advised to proceed with surgery, however she refused the operation due to personal reasons. On clinical examination the patient's abdomen resembled the clinical appearance of a full-term pregnant woman, with a firm and homogenously enlarged abdomen. Routine laboratory tests were within normal limits, while Ca-125 was markedly elevated, 938 $\mathrm{IU} / \mathrm{mL}$. An abdominal and chest computed tomography (CT) followed and showed the presence of a giant solid mass, originating from the left adnexa and measuring $22 \times 21$ $\mathrm{x} 18 \mathrm{~cm}$, without any signs of invasion in adjacent organs ( $F$ ig. 1A, B). It also revealed a large right sided pleural effusionhydrothorax with concomitant atelectasis and ascites. Pleuritic fluid aspiration was carried out to improve her respiratory 
Figure 1. (A, B): Axial (A) and coronal view of abdominal computed tomography (CT) showing the $22 \times 21 \times 18 \mathrm{~cm}$ solid mass with ascites
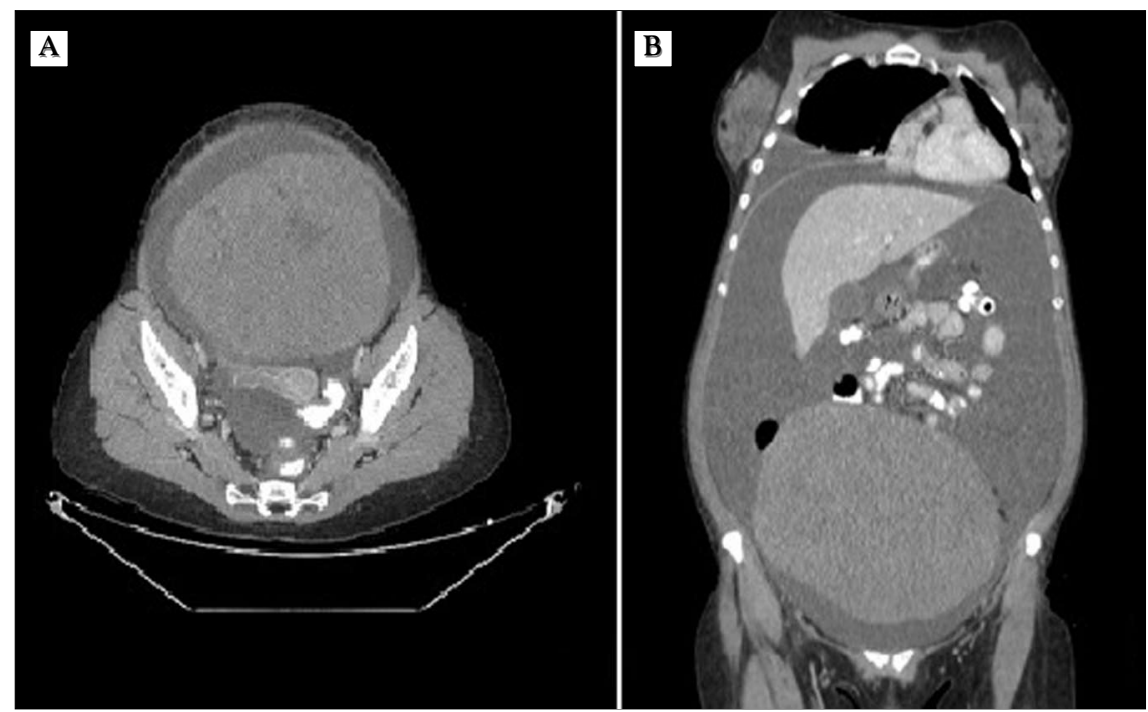

function and obtain fluid for cytology. The latter was negative for malignancy. Surgical intervention was decided with the presumptive diagnosis of ovarian carcinoma, aiming to optimal cytoreduction. Findings on laparotomy were: $4 \mathrm{~L}$ of ascetic fluid which was drained and a large tumor originating from the right ovary measuring $24 \times 18 \times 16 \mathrm{~cm}$ and $4.546 \mathrm{gr}$ in weight (Fig. $2 \mathrm{~A}, \mathrm{~B}$ ). Excision of the tumor and total abdominal hysterectomy with omentectomy and bilateral salpigooophorectomy were performed. Surprisingly, cytology of the ascetic fluid and final histopathology of the adnexal tumor showed no malignancy. Histopathological examination set the diagnosis of ovarian fibrothecoma, for the primary giant adnexal mass. Postoperative progress was unremarkable, with remission of the pleural effusion by the seventh postoperative day. The patient was discharged on the $10^{\text {th }}$ postoperative day and remains disease free and well in herself on follow up visits, 6 months later.

\section{Discussion}

Meigs' syndrome accounts for about 1\% of all ovarian tumors, and ovarian fibromas are

Figure 2. Intraoperative view of the giant adnexal mass (A) abdominal opening (B) - the mass extracted through the abdominal wall

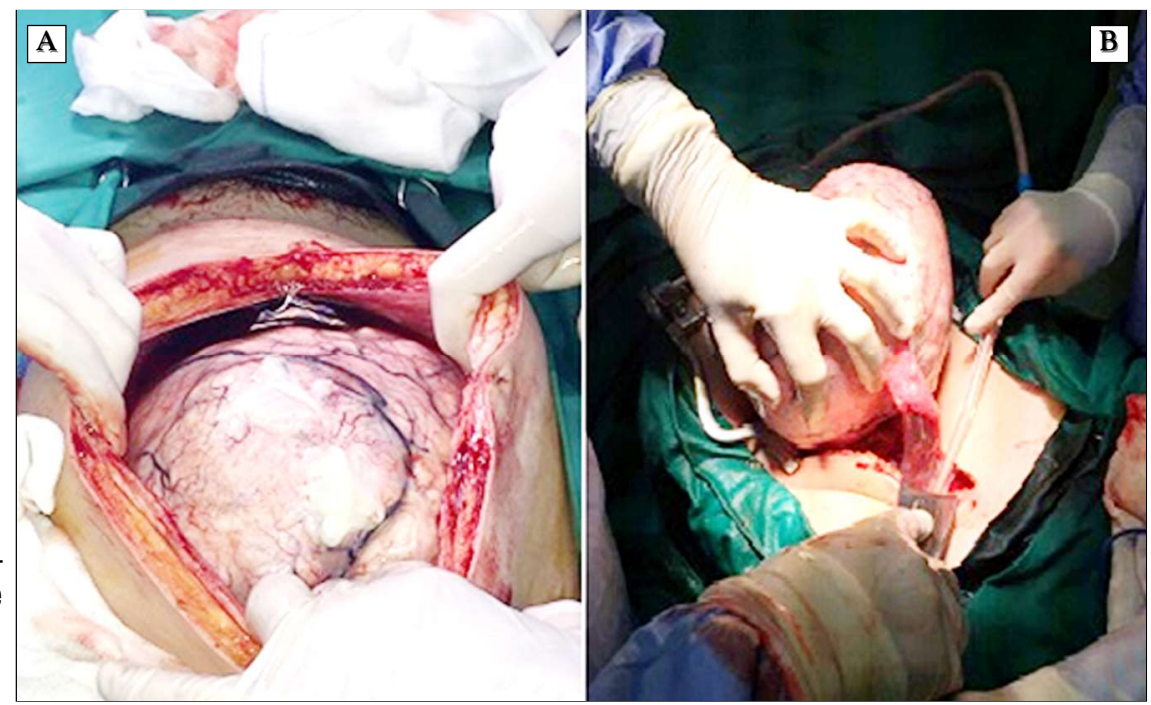


found in $2-5 \%$ of surgically removed ovarian tumors (4). About $10-15 \%$ of women with an ovarian fibroma have concomitant ascites, and $1 \%$ also has hydrothorax. In these cases, approximately $70 \%$ of pleural effusions are right sided, $15 \%$ are left sided, and $15 \%$ are bilateral (5). With appropriate clinical and surgical management, life expectancy for these patients is no different than the general population. Meigs' syndrome is very uncommon before the third decade of life, however progressively increases thereafter to peak in the seventh decade (6). Although the main clinical characteristics are the three mentioned above, other commonly reported symptoms are: dyspnoea (initially on exertion), fatigue, pelvic pain or bloating, constipation, swollen and distended abdomen with associated weight gain or weight loss, non-productive cough and amenorrhoea or irregular menstruations (7).

Pseudo-Meigs syndrome consists of pleural effusion, ascites, and benign tumors of the ovary other than fibromas $(8,9)$. These benign tumors include those of the fallopian tube or uterus and mature teratomas, struma ovarii, and ovarian leiomyomas (10). This terminology sometimes also includes ovarian or metastatic gastrointestinal malignancies (11).

Pleural effusion and ascites can be found in many different pathological conditions, such as: nephrotic syndrome, ovarian cancer, colon cancer, metastatic breast cancer, tuberculosis, congestive heart failure or cirrhosis (12), and all the above comprise the differential diagnosis for this clinical scenario. Obviously though, pseudo-Meigs' syndrome is in the top of this differential diagnosis list, in which the main difference to the classic Meigs' syndrome is the type of the primary tumor responsible (fallopian tube, uterus, round ligament, mature teratomas, struma ovarii or ovarian leiomyomas, colon, breast and stomach) (13).

The pathophysiology of ascites accompanying ovarian tumors remains uncertain. An early theory was that the production of ascetic fluid originated by the tumor itself through its angiogenesis (14), while others suggested that, hormonal stimulation play an important role in ascites formation. Furthermore, the presence of a tumor in the abdomen may provoke the release of inflammatory mediators resulting in 'leaky' capillaries. A third simplistic suggestion was that a solid ovarian tumor could physically irritate the peritoneum and stimulate the overproduction of peritoneal fluid (1), or even compress on the peritoneal lymphatics, obstructing their normal function.

Pathophysiologically, a pleural effusion is caused by an imbalance between fluid production and fluid removal in the pleural space. Under normal circumstances, approximately $15 \mathrm{~mL} /$ day of fluid lies into this space, originating from the capillaries of the parietal pleura and is daily removed by the lymphatics of the pleura. The pleural effusion in Meigs' syndrome is typically found on the right, because the transdiaphragmatic lymphatic channels are larger in diameter on that side. The origin of this pleural effusion remains poorly explained, however the most prevalent theory is that is caused by ascites drained from the above mentioned lymphatic channels into the pleural cavity. However, in another entity called atypical Meigs' syndrome patients have pleural effusion without ascites, and the pathophysiology of pleural effusion development is thought 'enigmatic' in the absence of the ascites (15).

When the pleural fluid is protein- and $\mathrm{LDH}^{-}$ rich is called an exudate. This may be caused by capillaries with altered permeability due to infection, infarction, or tumor inflitration. Interleukins (ILs) and vascular endothelial growth factor (VEGF) are important regulators of vascular endothelial cell function and are thought to play a major role in peritoneal fluid accumulation, which is manifests as ascites. Increased levels of VEGF can be seen in ovarian tumors, resulting is ascites formation, indicating an inflammatory process as the underlying ascites pathophysiology mechanism (2).

$\mathrm{Ca}-125$ is a glycoprotein expressed by the embryonic coelomic epithelium and the amnion, found elevated in $80 \%$ of epithelial ovarian cancers (16). It can be found elevated in benign conditions as endometriosis, pelvic inflammatory disease, uterine leiomyoma, pleuritis, pericarditis, peritonitis and cirrhosis (17). The triad of Meigs' syndrome in associa- 
tion with high $\mathrm{Ca}-125$ suggests ovarian cancer, but when ascetic or pleural fluid cytology is negative for malignancy, clinicians should consider Meigs' syndrome in the differential diagnosis, as described in this case.

\section{Conclusions}

This syndrome is a pleasant surprise considering that an ovarian mass combined with ascites and pleural effusion, are interpreted as malignant in origin in most cases. However, Meigs' syndrome cannot be disregarded when a female patient with the above mentioned relevant features is encountered, underlying the fact that only final histopathology can set the diagnosis of malignancy, despite the striking sometimes clinical, imaging and laboratory features.

\section{Conflict of Interest}

All authors declare there is no conflict of interest regarding publication of this paper.

\section{References}

1. Meigs JV. Fibroma of the ovary with ascites and hydrothorax; Meigs' syndrome. Am J Obstet Gynecol. 1954;67(5):962-85.

2. Riker D, Goba D. Ovarian mass, pleural effusion, and ascites: revisiting Meigs syndrome. J Bronchology Interv Pulmonol. 2013;20(1):48-51.
3. Chandanwale SS, Pal SS, Kumar HB, Sammi AB. Serous Cystadenoma and Fibrothecoma: A Rare Combination in Collision Tumor of Ovary with Pseudo-Meigs Syndrome. J Pathol TransI Med. 2015;49(2):163-6.

4. Jin C, Dong R, Bu H, Yuan M, Zhang Y, Kong B. Coexistence of benign struma ovarii, pseudo-Meigs' syndrome and elevated serum CA 125: Case report and review of the literature. Oncol Lett. 2015;9(4):1739-1742.

5. Sahn SA. State of the art. The pleura. Am Rev Respir Dis. 1988;138(1):184234.

6. Yamamoto Y, Miyagawa Y, Ehara T, Koyama M, Nakamura S, Takeuchi D, et al. Three Cases of Pseudo-Meigs' Syndrome Secondary to Ovarian Metastases from Colorectal Cancer. Case Rep Surg. 2017:2017:5235368.

7. Kahan J, Banner R, Lutchman-Singh K. Breathlessness and abdominal swelling: a classic eponymous syndrome. BMJ. 2017;356:j382.

8. Taniguchi $Y$, Nishikawa $H$, Maeda N, Terada $Y$. Breathlessness, pleural effusions, fibromas, and Meigs syndrome: look beyond the chest and don't delay! Lancet. 2020;395(10223):e32.

9. Yaguchi A, Ban K, Koshida Y, Fujikami Y, Ogura E, Terada A, et al. PseudoMeigs Syndrome Caused by a Giant Uterine Leiomyoma with Cystic Degeneration: A Case Report. J Nippon Med Sch. 2020 ;87(2):80-86.

10. Dunn JS, Jr., Anderson CD, Method MW, Brost BC. Hydropic degenerating leiomyoma presenting as pseudo-Meigs syndrome with elevated CA 125. Obstet Gynecol. 1998;92(4 Pt 2):648-9.

11. Daoudi M, Herrak L, Ftouh ME, Achachi L. Pseudo-Meigs syndrome secondary to ovarian serous cystadenoma. Pan Afr Med J. 2019:33:11. French

12. Kyo K, Maema A, Shirakawa M, Nakamura T, Koda K, Yokoyama H. PseudoMeigs' syndrome secondary to metachronous ovarian metastases from transverse colon cancer. World J Gastroenterol. 2016;22(18):4604-9.

13. Kikowicz M, Gozdowska J, Durlik M. Massive Ascites of Unknown Origin: A Case Report. Transplant Proc. 2020;52(8):2527-2529. Epub 2020 Apr 8.

14. Rubinstein Y, Dashkovsky I, Cozacov C, Hadary A, Zidan J. Pseudo meigs' syndrome secondary to colorectal adenocarcinoma metastasis to the ovaries.J Clin Oncol. 2009;27(8):1334-6.

15. Krenke R, Maskey-Warzechowska M, Korczynski P, Zielinska-Krawczyk M, Klimiuk J, Chazan R, et al. Pleural Effusion in Meigs' Syndrome-Transudate or Exudate?: Systematic Review of the Literature. Medicine (Baltimore). 2015;94(49):e2114

16. Lin JY, Angel C, Sickel JZ. Meigs syndrome with elevated serum CA 125. Obstet Gynecol. 1992;80(3 Pt 2):563-6.

17. Loizzi V, Cormio G, Resta L, Fattizzi N, Vicino M, Selvaggi L. Pseudo-Meigs syndrome and elevated CA125 associated with struma ovarii. Gynecol Oncol. 2005;97(1):282-4. 